Priscilla S. Rogers

University of Michigan, Ann Arbor

\section{IN THIS ISSUE:}

\section{What Sources Have Inspired Our Research?}

$\mathrm{C}$ ollege and university restructurings, downsizing $\checkmark$ efforts of all kinds, budget cuts, and the like intensify the competitive pressures we face, both as members of academe and particularly as teachers and researchers in business communication, a field that is neither fully understood nor entirely appreciated as a research area. In his article titled "Making Choices in the Research University," Donald Kennedy, President Emeritus at Stanford University, wrote:

\begin{abstract}
Universities, like other organizations, must make choices, and now the choices are becoming painful. On the one hand, the business of the research university is the expanding universe of knowledge, so the domain of opportunity is huge - and growing exponentially. On the other hand, resources have suddenly become more constrained. How, under such circumstances, can universities keep what matters most, and discard other things that matter less? And who decides what matters? (1993, p. 127, emphasis mine).
\end{abstract}

Increased competition for research support is the reality. A 1991 study by the Office of Technology Assessment in Washington, DC, for example, reported that support for basic research was at almost exactly the same level at the beginning of the 1980s as it was in 1967. Given current pressures to significantly cut costs and reduce debt, it is conceivable that there may be less research funding in this decade.

Moreover, we face direct challenges to our field. Some of our constituencies continue to regard us as teachers - not as researchers - whose "subject isn't a subject but a method" (Daniel, 1983, p. 9), and it has even been suggested that business communication can be taught by "any of those from the business faculty who have the interest" (Ferris, 1991, p. 63). Hard as these comments may be to swallow, they are not entirely foreign to us. As Rentz recently observed, "We tend to be a minority area ... which means that there is a strong possibility that what we do is not generally

Author Note: The author thanks the ABC Research Think Tank participants who contributed the sources for this column: Bonita Betters-Reed, Deborah S. Bosley, Rebecca Burnett, Geoffrey A. Cross, Ann Hill Duin, Ron Dulek, Janis Forman, William P. Galle, Jr., Jenny Gilsdorf, Daphne Jameson, Christine Kelly, Susan Kleimann, Kitty O. Locker, Mohan R. Limaye, Margot Northey, John Penrose, Lamar Reinsch, Kathryn Rentz, Jone Rymer, Evelyn Jaffe Schreber, Annette Shelby, John Sherblom, Barbara Shwom, Gail Fann Thomas, Charlotte Thralls, and Iris Varner. understood by those we work with and for" (1993, p. 233).

On the one hand, this challenging (and sometimes hostile) environment prompts us to work harder in order to gain more "respectability" for our teaching (Locker, 1979) as well as for our research and, as a colleague of mine frequently says, "that ain't all bad." On the other hand, the undermining of business communication and the research that sustains it, inhibits our ability to secure funding, release time, and equitable teaching loads that afford us the same kind of opportunity enjoyed by colleagues in other areas.

How then should we proceed?

Seventy-eight percent of the Association for Business Communication members that Beard and Williams surveyed agreed that "to further evolve as an academic discipline, business communication needs to substantially increase the body of research in the field" (1993, p. 293, emphasis mine). Merely "expanding the universe of knowledge," as Kennedy suggests (1993, p. 127), may not distinguish us, however. Historian and sociologist of science Derek J. de Solla Price (1986) estimated that in this century the number of publications has increased an average of $6 \%$ to $7 \%$ per year, a growth rate exceeding that of the population in the industrial nations producing most of the research. Moreover, as Reinsch recently observed, we already produce "an oversupply of inferior goods" and "too much of the research in our field is of low quality" (Reinsch, 1993, p. 201). Simply doing more research will not matter much; doing rigorous research on "what matters most" very well may.

Supported by the ABC Board and sponsored by the Research Committee, the Research Think Tank at the 1994 ABC International Conference in San Diego was organized to solicit from experienced researchers among our membership some ideas regarding the nature of research that "matters most." Think Tank participants spent a morning at the San Diego State University Faculty Club addressing the following question: What is significant about significant research? Through a series of structured brainstorming exercises, this "meeting of minds" generated numerous ideas that form the basis for analysis and commentary in this and a subsequent "Doing Research" column. The second column will present characteristics of significant research; this first column presents some of 
the significant sources that have influenced our research, sources that have mattered to our research colleagues.

\section{What Sources Inspire Our Research?}

If you were asked to name several sources that have greatly influenced your research, how would you respond? What research-based "artifacts" - articles, books, videos, or other resources - would you name? The 27 researchers who participated in the Think Tank at the 1994 Association for Business Communication (ABC) Conference in San Diego were asked to respond to these questions. Their responses generated a list of sources that is communally revealing and personally challenging as we reflect upon the significance of our research endeavors. This column describes how the Think Tank source list was obtained and why it is relevant. The column also offers a few observations about our field and our research community based on a preliminary analysis of the list.

\section{How Was the Source List Generated?}

The Think Tank source list was obtained as follows. Researchers who signed up for the Think Tank received a letter prior to the event in which they were asked to "consider beforehand one significant influence on your thinking about communication research in recent years (e.g. a scholarly article, PBS series)." Shortly after arriving at the Think Tank site, facilitator Susan Kleimann asked the participants to write on index cards "several sources that have significantly influenced your research." Throughout the Think Tank exercises, participants were encouraged to use these "source cards" for inspiration. Each time a particular source was the basis for a contribution, a participant was to put a hatch mark on the source card, an activity intended to remind participants to draw their contributions from their sources.

Participants were not to reveal their individual sources until the end of the session when, in an "around-the-campfire fashion," the sources were named. At this point it became clear that the sources were interesting in and of themselves, and a number of the participants suggested that they be compiled and published.

\section{Why Is the Source List Relevant?}

The source list generated by Think Tank participants does not comprise a scientific sample, and it must be interpreted with the full understanding that it did not result from an organized survey of $A B C$ members. Yet, it merits our attention, not only because it is intellectually interesting but also because the Think Tank participants comprised a group that mirrors our wider community: our diverse backgrounds, different communication areas, and varied research efforts during the last decade (see Author Note).
Even more significant, individual Think Tank participants are well-known for their contributions to research. The Think Tank group included two of our ABC Outstanding Researcher Award winners, past and present $A B C$ Presidents and Vice Presidents, and editors, associate editors, and board members of the journals most directly associated with our discipline: the Business Communication Quarterly, The Journal of Business of Communication, Journal of Business and Technical Communication, and Management Communication Quarterly. In these journals since 1984 Think Tank participants alone have published more than 100 articles covering a wide range of communication issues. Individual Think Tank participants are also among those known for their research on research (e.g. Rymer et al. 1994), and a number are regarded as individuals who provide vital research advice. For example, seven of the eight researchers who contributed to the June 1994 Doing Research column entitled "What Makes an Article Publishable?" (Locker, 1994), also participated in the research Think Tank.

Given the composition of the Think Tank group, it is safe to say that the sources they named are the sources that have influenced our research. Moreover, because the list (see the appendix) contains sources influencing our colleagues' research, it has something to tell us about our identity, both from a communal and a personal perspective.

\section{What Does the Source List Tell Us?}

In a recent issue of the Journal of Business Communication, which examined business communication as a field, guest editor Kathryn Rentz described our communal "longing for a stronger sense of identity" and our "collective desire to understand better the work that we are engaged in" (1993, p. 234). Rentz's sentiment recalls the "orphan motif" that Hagge (1986) identified as predominating at least 50 years of discussions about our field. Our so-called lack of identity, Hagge concluded in a subsequent article, stems in part from that fact that we do not have our "own specialized body of knowledge as do other disciplines" and therefore "business communication traditionally has latched onto the findings of other fields to legitimize itself" (1987, p. 89). It is clear from reviewing the Think Tank source list that we do indeed latch onto sources from other fields; it is also clear that our own literature has influenced our research. Both of these facts suggest that we may be less "orphan" than we believe.

Look at the Think Tank list. At first glance you see our diversity - sources range from Ackoff to Aristotle; from Faigley to Fielden; from Daft and Lengel to Ede and Lunsford. The fact that researchers in our Association draw inspiration from such a wide array of thinkers supports the notion that we are a "hybrid 
discipline" (Shaw, 1993) and may lend credence to the observation that we lack a "comprehensive theoretical grounding" (Shelby, 1988, p. 13). But also notice that among the sources are Aristotle, Bakhtin, Burke, Geertz, Foucault, Freud, Kuhn, Maslow, and Pepper, writers with universal appeal whose works belong to that corpus of literature that transcends disciplinary boundaries. One could argue that to confer with these sources does not dilute our disciplinary standing, nor is it by any means merely "borrowing" (Shaw, 1993, p. 299). Rather, these sources tie us to the worldwide research community, a connection that is our obligation - not our depreciation.

The source list also shows some evidence that we comprise a discourse community of our own. For one thing, some of us have been influenced by the same scholars: four Think Tank participants listed works by Burke, and the new strategy book by Eccles and Norhia was named by two participants. Aristotle, Ede and Lunsford, Ong, and Daft and Lengel appear not only on the Think Tank list but also as "most frequently cited" sources in the Reinsch and Lewis analysis of author and citation patterns for the Journal of Business Communication (1993). Moreover, the Think Tank list includes the research of three ABC members (Porter, Shelby, and Yates), as well as three citations from one of our journals. The fact that these connections exist at all may be surprising to some, while others may be discouraged by the fact that the connections are so few. But if "a discipline is essentially a conversation" (Rentz 1993, p. 237) then the Think Tank source list suggests that we are beginning to talk.

Also apparent from the list is the tug-of-war we encounter when negotiating between basic (theoretical-conceptual) research and applied (practitioneroriented) research in our field (see Limaye, 1993; Smeltzer, 1993; Suchan, 1993). One expects a source list of this kind to contain many theoretical works, which it does. Yet, some of the entries are clearly "applied," such as Fielden's classic Harvard Business Review article on business writing, The Female Advantage by Helgesen, and those highly digestible works on management practice by Quinn and Schein, books we might find prominently displayed at Borders Book Store. Obviously, some of the sources that inspire our research are works intended for "popular" digestion. As for the theoretical works, Foucault, Freud, Kuhn, and others may also grace the bookshelves of practitioners.

So what does the Think Tank source list suggest about our research community? Overall, it is probably safe to say, much as Reinsch and Lewis "tentatively" concluded from their analysis of citation patterns, that this source list supports the claim that "business communication is experiencing some of the same trends as other academic areas" namely, that we are interdisciplinary and that our publications comprise a "cumulating body of knowledge that supports current research" (1993, pp. 456-457). Indeed, business communication may be less "orphan" than our state-of-thefield analyses suggest.

Individually, the Think Tank source list can serve as a checklist for a personal inventory. During the process of completing the citations for the list, it was interesting to see how many of the sources I could find in my university office. Some were readily available and well worn from admiration; those missing in. cluded sources I have been meaning to read for years and sources that were entirely unfamiliar. Such an inventory is telling: familiar sources confirm collegial connections; unfamiliar sources suggest how little we know about each other.

Reading unfamiliar literature that is well known to colleagues may help us integrate the various "parent disciplines" from which we come (Rentz, 1993; Shaw, 1993). Most likely, the Think Tank source list bears little overall resemblance to the reading lists we encountered in research seminars or in preparation for preliminary examinations; for example, only three of the sources appear in Locker's hefty reading list for English 895: Research Methods for Rhetoric and Composition. Just plain curiosity may send you to the bookstore - my new acquisitions include Gay's biography of Freud, Postman's Technopoly, and Helgesen's The Female Advantage (in hardback no less). One wonders, what about these sources have colleagues found so appealing? Why do these sources "matter"? All in all, this last question may be the most important. If we are to compete effectively for the opportunity to contribute fully in the academy and beyond, we need to encounter research that "matters most" and then we must produce more of it ourselves. Toward that goal the Think Tank source list provides inspiration.

\section{REFERENCES}

Beard, J. D., \& Williams, D. L. (1993). A professional profile of business communication educators and their research preferences: Survey results. Journal of Business Communication, 30, 269-295.

Daniel, C. A. (1983). Remembering our charter: Business communication at the crossroads. Journal of Business Commu. nication, 20, 3-11.

Ferris, W. P. (1991). A humanistic approach to leadership skillbuilding. In J. D. Bigelow (Ed.), Managerial skills: Exploration in practical knouledge. Newbury Park, CA: Sage.

Hagge, J. (1986). Business communication, the orphaned disci. pline: A historical review of business communication teachers' perceptions of their field's place in the college curriculum. Proceedings of the 51st ABC international convention, 168 177.

Hagge, J. (1987). The process religion and business communication. Journal of Business Communication, 24, 89-120. 
Kennedy, D. (1993). Making choices in the research university. Journal of Academy of Arts and Sciences, 122,(4), 127-156.

Limaye, M. R. (1993). Relevance versus significance in business communication research [Letter to the editor]. Journal of Business Communication, 30, 463-472.

Locker, K. O. (1979). Making business communication courses academically respectable. ABCA Bulletin, 42(1), 6-10.

Locker, K. O. (Ed.). (1994). What makes an article publishable? Bulletin of the Association for Business Communication, 57(2), 59-66.

Office of Technology Assessment. (1991). Federally funded research: Decisions for a decade. Washington, DC: Author.

Price, D. J. (1986). Little science, big science ... and beyond. New York: Columbia University Press.

Reinsch, N. L., Jr. (1993). Why don't we do better research? Journal of Business Communication, 30, 200-202.

Reinsch, N. L., Jr., \& Lewis, P. V. (1993). Author and citation patterns for the Journal of Business Communication, 1978 1992. Journal of Business Communication, 30, 435-462.
Rentz, K. (1993). Negotiating the field of business communication [Editorial]. Journal of Business Communication, 30 , 233-240.

Rymer, J. (Ed.). (1994). Relationships in collaborative research teams. Bulletin of the Association for Business Communication, 57(1), 48-57.

Shaw, G. (1993). The shape of our field: Business communication as a hybrid discipline. Journal of Business Communication, . 30, 297-313.

Shelby, A. (1988). A macro theory of management communication. Journal of Business Communication, 25, 13-27.

Smeltzer, L. R. (1993). Relevance is the issue. Journal of Business Communication, 30, 477-478.

Suchan, J. (1993). Response to Mohan Limaye: The need for contextually based research. Journal of Business Communication, $30,473.476$.

An appendix appears on pages 61-63.

\section{There's more than one award waiting to be awarded in the wide world of $\mathrm{ABC}$ scholarship...}

The Outstanding Teaching Award described on page 70 is not the only honor $A B C$ bestows on dedicated teachers, researchers, and writers in our profession.

There's also the Outstanding Researcher Award, for which you may make nominations.

And the Francis W. Weeks Award of Merit for service and leadership.

And the C. R. Anderson Research Award, which makes grants toward research projects.

And the Alpha Kappa Psi Foundation Award for distinguished publication.

See what you have to aspire to? 